\title{
Fluid emissions at the Aquitaine Shelf (Bay of Biscay, France): A biogenic origin or the expression of hydrocarbon leakage?
}

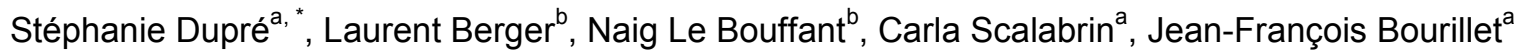 \\ a IFREMER, Unité Géosciences Marines, 29280 Plouzané Cedex, France \\ b IFREMER, Unité Navires et Systèmes Embarqués, 29280 Plouzané Cedex, France \\ *: Corresponding author : Stéphanie Dupré, tel.: +33298224709 ; fax: +33298224549 ; email address : \\ stephanie.dupre@ifremer.fr
}

\begin{abstract}
:
Fishery acoustic surveys conducted in the Bay of Biscay and dedicated to monitoring and predicting pelagic ecosystem evolution reveal numerous active seeps on the Aquitaine Shelf, east of the shelf break, at water depths ranging from 140 to $185 \mathrm{~m}$. Some acoustic anomalies recorded in the water column with hull-mounted single and multibeam echosounders are clearly caused by fluid escape at the seabed, most likely gases. These fluid emissions are associated at the seafloor with high backscatter subcircular small-scale mounds, on average less than $2 \mathrm{~m}$ high and a few metres in diameter. Based on near-bottom video and acoustic surveys, these mounds are interpreted to be byproducts of gas seepage, possibly methane-derived authigenic carbonates. The spatial distribution of the seeps and related structures, based on water column acoustic gas flares and high backscatter seabed patches, appears to be relatively broad, with a North-South extension of $\sim 65 \mathrm{~km}$ across the Parentis Basin and the Landes High, and a West-East extension along a few kilometres wide on the shelf. The seepage activity seems persistent through time at the annual scale, with acoustic evidence dating back to 1998. The spatial distribution of the fluid emissions at the Aquitaine Shelf may suggest possible sedimentary and tectonic controls in relation with the Pyrenean compression phase. The nature and the origin of the emitted fluids and seafloor mounds are unknown. The gases may correspond to biogenic methane from Late Pleistocene deposits or to thermogenic gases originating from deeper, Jurassic-Cretaceous levels. The oil province of the Parentis Basin raises questions regarding possible genetic links to the petroleum system.
\end{abstract}

\section{Highlights}

Persistent seepage activity at the Aquitaine Shelf (Bay of Biscay, France). Widespread gas emissions east of the shelf break at 140-185 m water depths. Small-scale subcircular mounds associated with high backscatter seafloor. Possible methane-derived carbonates at the seabed.

Keywords: Bay of Biscay ; Aquitaine Shelf ; Parentis Basin ; Fluid ; Seepage ; Acoustics 


\section{Introduction}

Seepage activity at continental margins is a relatively widespread phenomena (Judd and Hovland, 2007), emphasized in particular by the increase in multibeam seabed and water column mapping and technological advances in the last decade (e.g. Dupré et al., 2008, 2010a; Mascle et al., 2014). Seeps may occur at shallow water depths in the proximal domain (Baltzer et al., 2014; Damm et al., 2005; García-Gil et al., 2011; Hovland, 2002; Jensen et al., 1992; Laier et al., 1992; Levin et al., 2000), as in deep basins (Dupré et al., 2010b; Foucher et al., 2010). Fluid escape and seep-related structures at the seabed, e.g., authigenic carbonate structures (Aloisi et al., 2002b; Bayon et al., 2009b), pockmarks (Gillet et al., 2008), brine pools (Woodside and Volgin, 1996), and mud volcanoes (Dupré et al., 2007), may be the surface expression of deeper processes (Deville et al., 2003; Dupré et al., 2014; Loncke et al., 2004). Fluid emissions may be associated with water, oil, and gas, including hydrogen sulfide, carbon dioxide (McGinnis et al., 2011), biogenic methane (Laier et al., 1992) and thermogenic gases (Prinzhofer and Deville, 2013). Fluid escape through the seabed to the water column can be recorded acoustically with deep-towed side scan sonars (Dupré et al., 2010b; Merewether et al., 1985), as well as single beam (Foucher et al., 2010; Greinert et al., 2006; Nikolovska et al., 2008) and multibeam (Dupré et al., 2010a) echosounders.

The present study focuses on acoustic signatures of water column fluid emissions and seeprelated structures at the seabed of the Aquitaine Shelf (Bay of Biscay, France). This fluid system was discovered only recently by the reviews of ship-borne single and multibeam data acquired during the fishery resource assessment cruises conducted by Ifremer (Petitgas et al., 2009).

\section{Geological setting}

The Mesozoic Aquitaine Basin located in southwestern France comprises several sub-basins, including the Parentis Basin which is filled with $15 \mathrm{~km}$ of sediments above a relatively thin crust (Biteau et al., 2006; Bois and Gariel, 1994). The tectonic history of the Parentis Basin was controlled by two major phases. Rifting initiated in the Early Cretaceous, mainly along the $\sim \mathrm{W}-\mathrm{E}$ Ibis fault (Fig. 1a) (Jammes et al., 2010), and aborted at the end of the Albian. The Pyrenean compression phase ranged from the Late Cretaceous to the middle Eocene. The Parentis Basin is a proven oil province with reservoirs from the Upper Kimmeridgian-Barremian in relation to Late Jurassic shaly-carbonates source rocks (Biteau et al., 2006; Bois and Gariel, 1994). The Aquitaine Margin is characterized by Triassic salt deposits forming diapirs and related fault systems (Biteau et al., 2006; Bois and Gariel, 1994).

The studied area is located offshore along the Aquitaine Shelf between the Cap Ferret and Capbreton canyons, within the French Exclusive Economic Zone (EEZ), in the Parentis Basin and in the northern part of the Landes High (Fig. 1).

Pockforms and pockmarks have been identified respectively in the deeper parts within the Spanish EEZ (Iglesias et al., 2010), and south of the Capbreton canyon (Gillet et al., 2008) (Fig. 1a). This latter pockmark field, located at water depths between 400 and $800 \mathrm{~m}$, is interpreted as being related to upward fluid migration from sediment filling of buried paleocanyons in relation with the Capbreton canyon system (Gillet et al., 2008).

Figure 1. a) Shaded bathymetry map of the Aquitaine Margin (Bay of Biscay). Gas seeps identified in the present study are located on the Aquitaine Shelf within the French EEZ in the Parentis Basin and in the Landes High. The dashed lines are the limits, from north to south, between the Armorican Shelf and the Parentis Basin and between the Parentis Basin and Landes High, respectively (Bois and Gariel, 1994). The two green stars mark the northern and southern limits of the seep domain identified in this study, based on seafloor backscatter data 
from the North-South Pelgas 2011 profile shown in Fig. 1b. Known seep-related morphologies at the seabed, a pockmark field south of the Capbreton canyon (Gillet et al., 2008) and pockforms in the distal domain (Iglesias et al., 2010), are reported with locations of the ECORS (Bois and Gariel, 1994) and Sparker (Bellec and Cirac, 2010) seismic profiles discussed in this paper.

b) Zoom of the studied area with backscatter seafloor coverage from the Itsas (1998 and 2001), Bobgeo2 (2010) and Pelgas 2011 cruises. High backscatter seafloor patches identified along the Itsas (Sterckeman et al., 2009) and Pelgas 2011 profiles, and interpreted as seep-related structures, are reported. Locations of the acoustic gas flares shown in Figs. 2 to 6 are indicated.

\section{Dataset}

The acoustic water column dataset was acquired during Pegase98 (1998) and Pelgas (20002011), marine expeditions dedicated to monitoring and predicting pelagic ecosystem evolution in the Bay of Biscay using the acoustic facilities of the Research Vessel (R/V) Thalassa (Petitgas et al., 2009). Two ship-borne echosounders, a Simrad EK60 single beam and recently (since 2008) a ME70 calibrated multibeam, equipped the R/V Thalassa. The multibeam echosounder was developed by Ifremer together with the manufacturer Simrad, for details of the system see Trenkel et al. (2008). The EK60 system operates simultaneously at 18, 38, 70, 120 and $200 \mathrm{kHz}$ while the ME70 multibeam system runs between $70-120 \mathrm{kHz}$. These echosounders image and record both the water column and the seafloor. The ME70 multibeam data provide valuable information on the seabed morphology and the nature of the subseafloor, respectively, with the bathymetry and seabed backscatter. Post-processing of the ME70 acoustic signal has been set up by Le Bouffant et al. (2013). A remote operated towed vehicle, the EROC (Engin Remorqué d'Observation de Chalut, (C) Ifremer, Doray et al., 2011), surveyed some of the seeps at the Aquitaine Shelf in 2011 at $2 \mathrm{kn}$ speed. The EROC system is equipped with a black and white video and an EK60 $200 \mathrm{kHz}$ single beam echosounder providing ground-truth information and high acoustic resolution of the detected targets, respectively.

The Movies 3D software (Clfremer, see e.g., Trenkel et al. 2009) was used to replay and process the water column acoustic data presented in Figs. 2 to 6 as $2 \mathrm{D}$ water column echograms and 3D views.

In addition to the acoustic Pegase98 (1998) and Pelgas (2000-2011) datasets, backscatter seafloor images acquired during the Itsas (1998 and 2001) and Bobgeo2 (2010) cruises were also integrated in the study.

\section{Results}

Numerous and various echoes are recorded in the water column along the Aquitaine Shelf, caused by the presence of aquatic organisms (e.g., Trenkel and Berger, 2013) and gas bubbles (this study). Backscatter from swimbladder fish is mainly produced by their gas-filled bladder which shows a very strong impedance contrast with the fish flesh and the seawater (Foote, 1980). A similar impedance contrast applies for gas bubbles, which are small in size compared to swimbladders. According to the linearity principle, Foote (1983) and Rottingen (1976) used a basic assumption to relate the backscattered intensity to fish density; it can similarly be assumed that the backscatter would be proportional to bubble density. The acoustic anomalies interpreted as the presence of gas bubbles in the water column will be referred to as -gas flares" after Obzhirov et al. (2004). One of the main differences in acoustic records between fishes and bubbles is the shape of the echoes. Gas emissions form elongated flares rooted at the seafloor, subvertical or slightly inclined depending on the current (Figs. 2-4). 
In ship-borne single beam echograms (Fig. 2), gas bubbles are detected over the entire range of frequencies $(18,38,70,120$ and $200 \mathrm{kHz})$, with an enhanced signal at $18 \mathrm{kHz}$. For frequencies higher than $18 \mathrm{kHz}$, bubble echoes are smothered by echoes from small objects including fluid organisms, plankton, and tiny gas-bearing organisms with resonant backscatter around $50 \mathrm{kHz}$ (Trenkel and Berger, 2013). An ER60 $200 \mathrm{kHz}$ single beam towed at $30 \mathrm{~m}$ above the seabed with the EROC system (Fig. 7a) provided high-resolution acoustic records of gas flares emitted from the close surroundings of a $8 \mathrm{~m}$ wide subcircular mound (Fig. 6d). Multibeam ([70-200 $\mathrm{kHz}]$ ) water column data provide 3D views of the gas flares (Figs. 4, 6b and 6c).

Fluid emissions recorded at the Aquitaine Shelf occur between water depths of 140 and $185 \mathrm{~m}$ (Fig. 1), and reach tens of metres above the seafloor (Figs. 2-4 and 6) with some reaching close to the sea surface (Figs. 3c, 4a and b). Seepage appears persistent through time based on 16 years of records, from 1998 to 2013 (Figs. 2-6). See examples along the 4404'N West-East transect (Figs. 2 and 3).

Gas flares are associated at the seabed with subcircular features less than $2 \mathrm{~m}$ high and a few metres in diameter on average (Figs. 2b, 2f, 5a and 6d). There is no evidence for the presence of pockmarks at the seabed, only positive reliefs are identified.

These small-scale mounds are systematically associated with high backscatter seabed patches (Fig. 5b). Available seafloor backscatter data from the Pelgas 2011, Itsas (Sterckeman et al., 2009) and Bobgeo2 cruises provide complementary information on the spatial distribution of seeps and seep-related structures at the seabed (Fig. 1b). High backscatter seabed patches are mainly located close to the shelf break, with the highest densities identified in the southern part of the Pelgas 2011 and Itsas dataset (Fig. 1b), in accordance with the acoustic gas flare distribution (Fig. 1).

Seabed observations via the EROC video system (Fig. 7a) (see pictures extracted from the video in Figs. $7 b$ and $c$ and the video available as supplementary data) revealed structures that resemble authigenic carbonates that commonly precipitate in seeping environments (Aloisi et al., 2002a; Bayon et al., 2009b; Jensen et al., 1992; Pierre et al., 2012). The quality of the images and the relatively high-speed survey $(2 \mathrm{kn})$ were not suitable for observing gas bubbles. Despite the poor quality of the image, a thin sedimentary layer appears to partly cover these mounds.

The near-bottom video also provides information on the fauna, although limited. Numerous sponges scatter the seafloor and are found on top of and closely surrounding the small-scale mounds, visible due to their size and optical contrast with the sediments and rocks. Away from these structures, the density of the sponges seems to decrease.

Figure 2. $2 \mathrm{D}$ echograms showing water column acoustic anomalies recorded on the Aquitaine Shelf with the hull-mounted EK60 single beam echosounder of the R/V Thalassa from 1998 to 2007, at $18 \mathrm{kHz}$ (d, e), $38 \mathrm{kHz}(\mathrm{a}, \mathrm{b}, \mathrm{c})$ and $200 \mathrm{kHz}$ (f). The threshold is set to $-70 \mathrm{~dB}$. Acoustic gas flares are located at water depths ranging between 140 and $185 \mathrm{~m}$. The 1998 echogram is located along the $44^{\circ} 00^{\prime} \mathrm{N}$ West-East transect while the others acquired between 2000 and 2007 correspond to the $44^{\circ} 04^{\prime} \mathrm{N}$ West-East transect; each of these latter are at different longitude, therefore imaging different seeping sites (Fig. 1).

Figure 3. 2D echograms showing water column acoustic anomalies, recorded on the Aquitaine Shelf with the hull-mounted EK60 $18 \mathrm{kHz}$ single beam echosounder of the R/V Thalassa, along the $44^{\circ} 04^{\prime} \mathrm{N}$ West-East transect (see location in Fig. 1). The threshold is set to $-70 \mathrm{~dB}$. Two seeping sites, $A$ and $B$, both investigated at two different years appear persistent in their activity . The seeping site A was surveyed in 2007 (a) and 2010 (b) and is characterized by two distinct gas flares reaching $80 \mathrm{~m}$ above the seafloor and located at $165 \mathrm{~m}$ water depth. The second site, B, was surveyed in 2008 (c) and 2009 (d) and is located at 145 m water depth.

Figure 4. 3D views of water column acoustic anomalies recorded with the hull-mounted ME70 multi-beam echosounder of the R/V Thalassa operated at [70-120] kHz at $\sim 160 \mathrm{~m}$ water depths a) in 2010 along the $44^{\circ} 04^{\prime} \mathrm{N}$ East-West transect and b) in 2011 along the North-South Pelgas 
profile. See locations in Fig. 1. The threshold is set to $-60 \mathrm{~dB}$ and $-65 \mathrm{~dB}$ in a) and b), respectively. The acoustic water column of the Aquitaine Shelf is very much disturbed both by biomass (numerous fish schools, planktonic levels) and gas bubbles.

Figure 5. a) Bathymetry and b) backscatter signature of seep-related structures identified on the Aquitaine Shelf based on ME70 multibeam echosounder data acquired during the Pelgas 2010 cruise (see location in Fig. 1).

Figure 6. ME70 and EROC-ER60 $200 \mathrm{kHz}$ water column and seabed multibeam data acquired during the Pelgas 2011 cruise along a North-South profile (see location in Fig. 1) over a seeping area at $160 \mathrm{~m}$ water depth (see Fig. 4b).

a) Gas flare imaged in the across-beams 2D view (left panel) and the corresponding longitudinal echogram along the $1200 \mathrm{~m}$ vessel track showing at least three gas flares and biological echoes (right panel). The threshold is set to $-70 \mathrm{~dB}$.

$\mathrm{b}$ and c) Acoustic 3D views of the same gas flares with a threshold set to $-60 \mathrm{~dB}$ and $-65 \mathrm{~dB}$, respectively, with one sample out of ten per beam. Acoustic samples are positioned in 3D using the two phase angles from the split beam interferometric processing (Le Bouffant et al., 2013).

d) Acoustic gas flares detected by the EROC-200 kHz single beam echosounder (surveying at $\sim 30 \mathrm{~m}$ above the seafloor) associated at the seabed with a small-scale mound of 8 metres in diameter and less than 1 metre high.

Figure 7. a) Towed EROC video system (Ifremer) with b, c) near-bottom seabed pictures taken during the Pelgas cruise in 2011 above active seeps on the Aquitaine Shelf at $160 \mathrm{~m}$ water depth (Fig. 6). The mounds identified below acoustic gas flares may correspond to authigenic carbonates. Note the numerous sponges that scatter the seabed. d) Near bottom pictures in the Gulf of Alaska (Snakehead Bank at 75-150 m water depths) showing similar seabed structures to those observed on the Aquitaine Shelf (Jones et al., 2012). The Snakehead Bank is known to be the locus of active gas methane seeps, identified by acoustics and video.

\section{Discussion and conclusions}

Active and persistent gas seeps. Numerous active gas seeps have been discovered on the Aquitaine Shelf at water depths of 140 to $185 \mathrm{~m}$. Acoustic records from 1998 to 2013 reveal a persistence of seepage activity, at least at the annual scale (see e.g. Fig. 3). Local temporal variability at shorter time scales, as commonly observed elsewhere (e.g., Bayrakci et al., 2014; Foucher et al., 2010), is however not excluded.

Spatial distribution of the seepage activity. The eastern and western boundaries of the seep domain are not fully constrained due to the acoustic and sampling strategy of the Pelgas surveys. However, based on seafloor backscatter data from the Itsas cruises, although with a small coverage (Fig. 1b), the seep-related structures appear localized east of the shelf break along a $\sim 5 \mathrm{~km}$ wide band in the West-East direction. Far east of the shelf, there are no evidence for seep-relates structures. This view is in accordance with the acoustic gas flare distribution, with seeps distributed along at least $\sim 65 \mathrm{~km}$ along a north-south oriented axis, between the Cap Ferret and the Capbreton canyons. The most eastward gas flare is located $\sim 10 \mathrm{~km}$ east of the shelf beak (Fig. 1). The presence of active and former seeps westwards in the deeper parts of the basin should not be excluded. Within the Spanish EEZ, pockforms have been already identified at the seabed ( $>\sim 1200 \mathrm{~m}$ water depths) and interpreted by Iglesisas et al. (2010) as possible fluid-related features (Fig. 1). The potential link between these pockforms and the active gas seeps on the French Aquitaine Shelf cannot be determined without further investigation. The seeping area identified in this study corresponds to the offshore Parentis Basin and to the northern part of the Landes High (Fig. 1). Within this identified seep domain, several clusters with higher densities of gas flares and high-backscatter small-scale mounds are present (Fig. 1). 
Seep-related structures. The acoustic gas flares recorded in the water column of the Aquitaine Shelf are not associated with pockmarks but with positive metre-scale reliefs systematically characterized by high backscatter seabed patches. These latter features are well known at other margins where they correspond to authigenic carbonate structures (Bayon et al., 2009b; Dupré et al., 2010b). Gas may escape through carbonates if porosity allows, or may occur preferentially at the edges of the carbonate structures (Dupré et al., 2010b). The mounds on the Aquitaine Shelf are interpreted as seep-related structures most likely built by precipitation of authigenic carbonates. Ground-truthing via towed video support this interpretation by revealing the presence of rocks resembling authigenic carbonates (Fig. 7 and video, see supplementary data). Methane-derived authigenic carbonates have been previously reported, for instance, off the Danish coast at 10-12 m water depths in conjunction with acoustic and video evidence for gas emissions (Jensen et al., 1992). Another shallow water site, very similar to the Aquitaine Shelf seeping area, has been described at the Snakehead Bank in the Gulf of Alaska (Jones et al., 2012). Methane gas emissions have been discovered there at 75-150 m water depths with acoustic systems and video. Morphological structures at the seabed, most likely seep-related structures although not yet analyzed, present a strong resemblance (Fig. 7d) to the seep-related mounds identified on the Aquitaine Shelf (Figs. 7b and c, see video in supplementary data). Sampling together with mineralogical and isotopic analyses of the Aquitaine Shelf mounds would determine the nature and origin of these structures and if they are methane-derived authigenic carbonates.

The absence of pockmarks at the Aquitaine Shelf seabed may be related to slow gas fluxes, which lead instead to precipitation of authigenic carbonates and eventually, if seepage activity is persistent enough, to mound-like structures (Roberts, 2001) as observed on the bathymetry (Figs. 2b, 2f, 5a and 6d) and video (Fig. 7b and c). The formation of metre-high carbonate structures would require a relatively continuous seepage through time, over at least tens of ky. Although we have evidence of seepage persistence at the annual scale, seep activity could be constrained over longer time scales with U/Th dating (Bayon et al., 2009a).

Ecosystems. The diversity and distribution of benthic fauna in relation with seeps is poorly constrained at the Aquitaine Shelf despite decades of investigation. The chemio-synthetic biota, including microbial mats and symbiont-bearing invertebrates, e.g. bivalves and polychaetes (Levin et al., 2000; Vanreusel et al., 2009), may be expected there, sustained by gas release. Sponges are observed with higher density in the vicinity of and on the top of the mounds, which are interpreted as seep-related structures, than away from them. Other species may be present at the seafloor or within the sediments but were not visible in the recorded video, in particular endofauna, e.g. polychaetes that may be present at cold seeps in shallow waters or in the deep sea. In the shallow waters off the Danish coast (northern Kattegat), for example, methanederived authigenic carbonates support a diverse ecosystem ranging from (symbiotic) bacteria to macroalgae and anthozoans (Jensen et al., 1992). Many animals live there within the rocks in holes bored by sponges, polychaetes and bivalves. Benthic fauna in relation with seeps on the Aquitaine Shelf, although poorly constrained, may point to localized and relatively poorly developed chemosynthetic communities, possibly due to low gas fluxes, bottom currents and predation pressure (Sahling et al., 2003). Megafauna at seeps may include many nonsymbiontbearing species, which profit in a variety of ways from the biomass and productivity of chemosynthetic megafauna (Vanreusel et al., 2009). Some active centres of mud volcanoes are characterized by high bioactivity in the near-bottom water column, with a large diversity and abundance of organisms (Vanreusel et al., 2009) and dense accumulations of larvae of crustaceans and fishes (Dupré et al., 2007). For example, the Zoarcidae is a typical fish family encountered at cold seeps (Biscoito et al., 2002; Gebruk et al., 2003) with some endemic species likely having adapted to the toxic environment. The high concentration of living organisms potentially reflects the availability of food in relation to the activity of the mud volcano. Similar to the mud volcanoes, fluid escape structures on the Aquitaine Shelf may serve to attract some species of fish. The Bay of Biscay is a well known and prolific pelagic fishery area, in particular with anchovies at Aquitaine Shelf (Trenkel et al., 2009) where numerous active seeps have been identified. Similarly, the Snakehead Bank (Gulf of Alaska), located at $75-150 \mathrm{~m}$ water 
depths and where shelf rockfishes are abundant, is also the locus of methane gas seeps and structures at the seabed that resemble to authigenic carbonates (Jones et al., 2012).

Further investigation would be required to determine the possible role of the seeps with regard to the presence of fish, for example with respect to their involvement in the food chain and in providing suitable substrate habitats via the formation of carbonate structures.

Nature and origin of the fluids. The acoustic gas flares recorded on the Aquitaine Shelf may correspond to biogenic methane (Fig. 8a), possibly originating from Late Pleistocene deposits (Bellec and Cirac, 2010), or to thermogenic methane and higher hydrocarbons with a deeper origin (Fig. 8b) from Jurassic-Cretaceous levels (Bois and Gariel, 1994), or a combination of the both. Most of the identified gas seeps are located within the Parentis Basin, roughly from the centre of the Parentis Trough (Biteau et al., 2006; Bois and Gariel, 1994) to the southern edge of the basin (Figs. 1 and 8). The southern limit of the seep domain lies at the Landes High. In case of thermogenic gases, the salt present on the Aquitaine Margin could play a role in the occurrence and therefore in the spatial distribution of the seeps by 1) contributing to organic material trapping and maturation and 2) subsequently providing suitable conduits for fluid migration and expulsion at the seabed via the fault network in relation with salt tectonics (Dupré et al., 2014; Huguen et al., 2009; Loncke et al., 2006).

Whatever the fluid origin, the spatial distribution of the identified seeps may suggest a possible relation with the stress regime and faults induced by the Pyrenean compression phase.

Further investigation involving sampling and geochemical analyses is required to determine the nature and origin of the emitted fluids and the possible genetic link with the hydrocarbon system of the Parentis Basin, a known oil province (Biteau et al., 2006; Bois and Gariel, 1994).

Figure 8. Seep distribution along selected seismic profiles (see location in Fig. 1).

a) West-East Sparker profile located in the centre of the South-Aquitaine shelf (Bellec and Cirac, 2010). The soft cover (U1) deposits on the substratum with a basal erosive surface (S1) and may be defined by three domains, the outer zone characterized by prograding deposit units, the median zone where the $\mathrm{U} 1$ is thin, and the inner zone. See details in Bellec and Cirac (2010).

b) South-North deep seismic profile from the ECORS project (Pinet and Montadert, 1987) across the Parentis Basin, with locations of exploration wells (Bois and Gariel, 1994). PP PlioQuaternary, M Miocene, O Oligocene, E Paleocene-Eocene, IC late Cretaceous, Ab Albian, Ap Aptian, NB Neocomian-Barremian, J Jurassic, TR Triassic, Black Triassic salt body, Pz Paleozoic sediment, HAR High Amplitude Reflection.

\section{Supplementary data}

Video. Near-bottom video survey above active gas emission sites characterized by metre scale mounds on the Aquitaine Shelf at $160 \mathrm{~m}$ water depths.

\section{Acknowledgments}

We would like to express many thanks to the officers and crews of the R/Vs Thalassa and Pourquoi pas ?, the chief scientists of the Pelgas and Itsas cruises, and the EROC fisheries technology team at Ifremer in Lorient. Aurore Steckerman and Mathieu Veslin (Ifremer) provided information on the distribution of seep-related structures based on seafloor backscatter analyses of Itsas ship-borne multibeam data. The video available as supplementary data was set up by Stephane Lesbats (Ifremer). We are grateful to Catherine Pierre (Université Pierre et Marie Curie, Paris) and Karine Olu (Ifremer, Brest) for fruitful discussion. Also acknowledged are valuable suggestions and improvements from two anonymous reviewers. 
Aloisi, G., Bouloubassi, I., Heijs, S.K., Pancost, R.D., Pierre, C., Damste, J.S.S., Gottschal, J.C., Forney, L.J., Rouchy, J.M., 2002a. CH4-consuming microorganisms and the formation of carbonate crusts at cold seeps. Earth and Planetary Science Letters 203, 195-203. doi:10.1016/s0012-821x(02)00878-6

Aloisi, G., Pierre, C., Rouchy, J.M., Faugeres, J.C., 2002b. Isotopic evidence of methane-related diagenesis in the mud volcanic sediments of the Barbados Accretionary Prism. Continental Shelf Research 22, 2355-2372. doi:10.1016/s0278-4343(02)00061-4

Baltzer, A., Ehrhold, A., Rigolet, C., Souron, A., Cordier, C., Clouet, H., Dubois, S., 2014. Geophysical exploration of pockmarks and their spatio-temporal activity in the Bay of Concarneau, Southern Brittany. Geo-Marine Letters 34, 215-230. doi:10.1007/s00367-0140368-0

Bayon, G., Henderson, G.M., Bohn, M., 2009a. U-Th stratigraphy of a cold seep carbonate crust. Chemical Geology 260, 47-56. doi:10.1016/j.chemgeo.2008.11.020

Bayon, G., Loncke, L., Dupré, S., Caprais, J.C., Ducassou, E., Duperron, S., Etoubleau, J., Foucher, J.P., Fouquet, Y., Gontharet, S., Henderson, G.M., Huguen, C., Klaucke, I., Mascle, J., Migeon, S., Olu-Le Roy, K., Ondréas, H., Pierre, C., Sibuet, M., Stadnitskaia, A., Woodside, J., 2009b. Multi-disciplinary investigation of fluid seepage on an unstable margin: The case of the Central Nile deep sea fan. Marine Geology 261, 92-104. doi:10.1016/j.margeo.2008.10.008

Bayrakci, G., Scalabrin, C., Dupré, S., Leblond, I., Tary, J.-B., Lanteri, N., Augustin, J.-M., Berger, L., Cros, E., Ogor, A., Tsabaris, C., Lescanne, M., Géli, L., 2014. Acoustic monitoring of gas emissions from the seafloor. Part II: a case study from the Sea of Marmara. Marine Geophysical Research. doi 10.1007/s11001-014-9227-7, in press

Bellec, V.K., Cirac, P., 2010. Internal architecture of the soft sediment cover of the SouthAquitaine shelf (Bay of Biscay): A record of high frequency sea level variations? Comptes Rendus Geoscience 342, 79-86. doi:10.1016/j.crte.2009.09.007

Biscoito, M., Segonzac, M., Almeida, A.J., Desbruyères, D., Geistdoerfer, P., Turnipseed, M., van Dover, C., 2002. Fishes from the hydrothermal vents and cold seeps - An update. Cahiers de Biologie Marine 43, 359-362

Biteau, J.-J., Le Marrec, A., Le Vot, M., Masset, J.-M., 2006. The Aquitaine Basin. Petrol. Geosci. 12, 247-273. doi:10.1144/1354-079305-674

Bois, C., Gariel, O., 1994. Deep seismic investigation on the Parentis basin (Southwestern France), Hydrocarbon and Petroleum Geology of France, edited by A. Mascle, Special publication of the European Association of Petroleum Geologists, pp. 173-186

Damm, E., Mackensen, A., Budéus, G., Faber, E., Hanfland, C., 2005. Pathways of methane in seawater: Plume spreading in an Arctic shelf environment (SW-Spitsbergen). Continental Shelf Research 25, 1453-1472. doi:10.1016/j.csr.2005.03.003

Deville, E., Battani, A., Griboulard, R., Guerlais, S., Herbin, J.P., Houzay, J.P., Muller, C., Prinzhofer, A., 2003. The origin and processes of mud volcanism; new insights from Trinidad. Geological Society Special Publications 216, 475-490. doi:10.1144/GSL.SP.2003.216.01.31

Doray, M., Berger, L., Coail, J.-Y., Vacherot, J.-P., Gerard, B., Petitgas, P., 2011. In-situ measurements of the individual acoustic backscatter of European anchovy (Engraulis encrasicolus) and sardine (Sardina Pilchardus), with concurrent optical identification. International Council for the Exploration of the Sea Annual Science Conference, 19-23 septembre 2011, Gdansk. http://archimer.ifremer.fr/doc/00055/16637/

Dupré, S., Buffet, G., Mascle, J., Foucher, J.-P., Gauger, S., Boetius, A., Marfia, C., the AsterX AUV Team, the Quest ROV Team, the BIONIL Scientific Party, 2008. High-resolution mapping of large gas emitting mud volcanoes on the Egyptian continental margin (Nile Deep Sea Fan) by AUV surveys. Marine Geophysical Researches 29, 275-290. doi:10.1007/s11001-009-9063-3

Dupré, S., Mascle, J., Foucher, J.-P., Harmegnies, F., Woodside, J., M., Pierre, C., 2014. Warm brine lakes in craters of active mud volcanoes, Menes caldera off NW Egypt: evidence for 
deep-rooted thermogenic processes. Geo-Marine Letters 34, 153-168. doi:10.1007/s00367-014-0367-1

Dupré, S., Scalabrin, C., Géli, L., Henry, P., Grall, C., Tary, J.-B., Çagatay, M.N., Imren, C., the MARMESONET Scientific Party Team, 2010a. Widespread gas emissions in the Sea of Marmara in relation with the tectonic and sedimentary environments: Results from shipborne multibeam echosounder water column imagery (MARMESONET expedition, 2009). European Geosciences Union General Assembly 2010 12, 9429-9422

Dupré, S., Woodside, J., Foucher, J.-P., de Lange, G., Mascle, J., Boetius, A., Mastalerz, V., Stadnitskaia, A., Ondréas, H., Huguen, C., Harmegnies, F., Gontharet, S., Loncke, L., Deville, E., Niemann, H., Omoregie, E., Olu-Le Roy, K., Fiala-Medioni, A., Dählmann, A., Caprais, J.-C., Prinzhofer, A., Sibuet, M., Pierre, C., Sinninghe Damsté, J., NAUTINIL scientific Party, 2007. Seafloor geological studies above active gas chimneys off Egypt (Central Nile Deep Sea Fan). Deep Sea Research Part I: Oceanographic Research Papers 54, 1146-1172. doi:10.1016/j.dsr.2007.03.007

Dupré, S., Woodside, J., Klaucke, I., Mascle, J., Foucher, J.-P., 2010b. Widespread active seepage activity on the Nile Deep Sea Fan (offshore Egypt) revealed by high-definition geophysical imagery. Marine Geology 275, 1-19

Foote, K.G., 1980. Importance of the swimbladder in acoustic scattering by fish : A comparison of gadoid and mackerel tagert strengths. Journal of the Acoustical Society of America 67, 2084-2089. doi:10.1121/1.384452

Foote, K.G., 1983. Linearity of fisheries acoustics, with addition theorems, Journal of the Acoustical Society of America 73, 1932-1940. doi:10.1121/1.389583

Foucher, J.P., Dupré, S., Scalabrin, C., Feseker, T., Harmegnies, F., Nouzé, H., 2010. Changes in seabed morphology, mud temperature and free gas venting at the Hăkon Mosby Mud Volcano, offshore Northern Norway, over the time period 2003-2006. Geo-Marine Letters 30, 157-167. doi:1007/s00367-010-0193-z

García-Gil, S., de Blas, E., Martínez-Carreño, N., Iglesias, J., Rial-Otero, R., Simal-Gándara, J., Judd, A.G., 2011. Characterisation and preliminary quantification of the methane reservoir in a coastal sedimentary source: San Simón Bay, Ría de Vigo, NW Spain. Estuarine, Coastal and Shelf Science 91, 232-242. doi:10.1016/j.ecss.2010.10.038

Gebruk, A.V., Krylova, E.M., Lein, A.Y., Vinogradov, G.M., Anderson, E., Pimenov, N.V., Cherkashev, G.A., Crane, K., 2003. Methane seep community of the Håkon Mosby mud volcano (the Norwegian Sea): composition and trophic aspects. Sarsia 88, 394-403. doi:10.1080/00364820310003190

Gillet, H., Cirac, P., Lagié, B., 2008. Pockmarks on the southern margin of the Capbreton Canyon (south-eastern Bay of Biscay), XI International Symposium on Oceanography of the Bay of Biscay

Greinert, J., Artemov, Y., Egorov, V., De Batist, M., McGinnis, D., 2006. 1300-m-high rising bubbles from mud volcanoes at $2080 \mathrm{~m}$ in the Black Sea: Hydroacoustic characteristics and temporal variability. Earth and Planetary Science Letters 244, 1-15. doi:1007/s00367010-0193-z

Hovland, M., 2002. On the self-sealing nature of marine seeps. Continental Shelf Research 22, 2387-2394. doi:10.1016/S0278-4343(02)00063-8

Huguen, C., Foucher, J.P., Mascle, J., Ondréas, H., Thouement, M., Gontharet, S., Stadnitskaia, A., Pierre, C., Bayon, G., Loncke, L., Boetius, A., Bouloubassi, I., de Lange, G., Caprais, J.C., Fouquet, Y., Woodside, J., Dupré, S., 2009. Menes caldera, a highly active site of brine seepage in the Eastern Mediterranean sea: "In situ" observations from the NAUTINIL expedition (2003). Marine Geology 261, 138-152. doi:10.1016/j.margeo.2009.02.005

Iglesias, J., Ercilla, G., García-Gil, S., Judd, A., 2010. Pockforms: an evaluation of pockmark-like seabed features on the Landes Plateau, Bay of Biscay. Geo-Marine Letters 30, 207-219. doi:10.1007/s00367-009-0182-2

Jammes, S., Tiberi, C., Manatschal, G., 2010. 3D architecture of a complex transcurrent rift system: The example of the Bay of Biscay-Western Pyrenees. Tectonophysics 489, 210226. doi:10.1016/j.tecto.2010.04.023

Jensen, P., Aagaard, I., Burke, R.A., Dando, P.R., Jorgensen, N.O., Kuijpers, A., Laier, T., Ohara, S.C.M., Schmaljohann, R., 1992. Bubbling reefs in the Kattegat - Submarine 
landscapes of carbonate-cemented rocks support a diverse ecosystem at methane seeps. Marine Ecology Progress Series 83, 103-112. doi:10.3354/meps083103

Jones, D.T., Wilson, C.D., De Robertis, A., Rooper, C.N., Weber, T.C., Butler, J.L., 2012. Evaluation of rockfish abundance in untrawlable habitat: combining acoustic and complementary sampling tools. Fishery Bulletin 110, 332-343

Judd, A.G., Hovland, M., 2007. Seabed Fluid Flow. The Impact on Geology, Biology and the Marine Environment. Cambridge University Press, Cambridge

Laier, T., Jorgensen, N.O., Buchardt, B., Cederberg, T., Kuijpers, A., 1992. Accumulation and seepages of biogenic gas in northern Denmark. Continental Shelf Research 12, 11731186. doi:10.1016/0278-4343(92)90077-w

Le Bouffant, N., Berger, L., Lurton, X., 2013. Simple method for multiple soundings extraction for wide beamwidth echosounders. Proceedings of the first international conference on underwater acoustics, 23-26 June 2013, Corfu island, Greece. http://archimer.ifremer.fr/doc/00146/25719/

Levin, L.A., James, D.W., Martin, C.M., Rathburn, A.E., Harris, L.H., Michener, R.H., 2000. Do methane seeps support distinct macrofaunal assemblages? Observations on community structure and nutrition from the northern California slope and shelf. Marine Ecology Progress Series 208, 21-39. doi:10.3354/meps208021

Loncke, L., Gaullier, V., Mascle, J., Vendeville, B., Camera, L., 2006. The Nile deep-sea fan: An example of interacting sedimentation, salt tectonics, and inherited subsalt paleotopographic features. Marine and Petroleum Geology 23, 297-315. doi:10.1016/j.marpetgeo.2006.01.001

Loncke, L., Mascle, J., Fanil Scientific, P., 2004. Mud volcanoes, gas chimneys, pockmarks and mounds in the Nile deep-sea fan (Eastern Mediterranean): geophysical evidences. Marine and Petroleum Geology 21, 669-689. doi:10.1016/j.marpetgeo.2004.02.004

Mascle, J., Mary, F., Praeg, D., Brosolo, L., Camera, L., Ceramicola, S., Dupré, S., 2014. Distribution and geological control of mud volcanoes and other fluid/free gas seepage features in the Mediterranean Sea and nearby Gulf of Cadiz. Geo-Marine Letters 34, 89110tre. doi:10.1007/s00367-014-0356-4

McGinnis, D.F., Schmidt, M., DelSontro, T., Themann, S., Rovelli, L., Reitz, A., Linke, P., 2011. Discovery of a natural CO2 seep in the German North Sea: Implications for shallow dissolved gas and seep detection. J. Geophys. Res.-Oceans 116. doi:C03013 10.1029/2010jc006557

Merewether, R., Olsson, M.S., Lonsdale, P., 1985. Acoustically detected hydrocarbon plumes rising from 2-km depths in Guaymas Basin, Gulf of California. Journal of Geophysical Research 90, 3075-3085

Nikolovska, A., Sahling, H., Bohrmann, G., 2008. Hydroacoustic methodology for detection, localization, and quantification of gas bubbles rising from the seafloor at gas seeps from the eastern Black Sea. Geochemistry Geophysics Geosystems 9. doi:10.1029/2008GC002118

Obzhirov, A., Shakirov, R., Salyuk, A., Suess, E., Biebow, N.S.A., 2004. Relations between methane venting, geological structure and seismo-tectonics in the Okhotsk Sea. GeoMarine Letters 24, 135-139

Petitgas, P., Goarant, A., Masse, J., Bourriau, P., 2009. Combining acoustic and CUFES data for the quality control of fish-stock survey estimates. Ices Journal of Marine Science 66, 1384-1390. doi:10.1093/icesjms/fsp007

Pierre, C., Blanc-Valleron, M.-M., Demange, J., Boudouma, O., Foucher, J.-P., Pape, T., Himmler, T., Fekete, N., Spiess, V., 2012. Authigenic carbonates from active methane seeps offshore southwest Africa. Geo-Marine Letters 32, 501-513. doi:10.1007/s00367012-0295-x

Pinet, B., Montadert, L., 1987. Deep seismic reflection and refraction profiling along the Aquitaine shelf (Bay of Biscay). Geophysical Journal of the Royal Astronomical Society 89, 305-312. doi:10.1111/j.1365-246X.1987.tb04423.x

Prinzhofer, A., Deville, E., 2013. Origins of hydrocarbon gas seeping out from offshore mud volcanoes in the Nile delta. Tectonophysics 591, 52-61. doi:10.1016/j.tecto.2011.06.028 
Roberts, H.H., 2001. Fluid and gas expulsion on the northern Gulf of Mexico continental slope: Mud-prone to mineral-prone responses, Natural Gas Hydrates: Occurrence, Distribution, and Detection. AGU, Washington, DC, pp. 145-161. doi:10.1029/GM124p0145

Rottingen, I., 1976. On the relation between echo intensity and fish density. Fiskeridirektoratets Skrifter Serie Havunder Sokelser 16, 301-314

Sahling, H., Galkin, S.V., Salyuk, A., Greinert, J., Foerstel, H., Piepenburg, D., Suess, E., 2003. Depth-related structure and ecological significance of cold-seep communities-a case study from the Sea of Okhotsk. Deep Sea Research Part I: Oceanographic Research Papers 50, 1391-1409. doi:http://dx.doi.org/10.1016/j.dsr.2003.08.004

Sterckeman, A., Bourillet, J.-F., Augustin, J.M., Pierre, D., Alix, A.-S., Gillet, H., 2009. Caractérisation sédimentaire des fonds marins par segmentation d'images acoustiques, cas du plateau continental aquitain. 12ème Congrès de I'ASF, Rennes, France. Abstract, 64

Trenkel, V.M., Berger, L., 2013. A fisheries acoustic multi-frequency indicator to inform on large scale spatial patterns of aquatic pelagic ecosystems. Ecological Indicators 30, 72-79. doi:10.1016/j.ecolind.2013.02.006

Trenkel, V.M., Berger, L., Bourguignon, S., Doray, M., Fablet, R., Massé, J., Mazauric, V., Poncelet, C., Quemener, G., Scalabrin, C., Villalobos, H., 2009. Overview of recent progress in fisheries acoustics made by Ifremer with examples from the Bay of Biscay. Aquatic Living Resources doi: 10.1051/alr/2009027

Trenkel, V.M., Mazauric, V., Berger, L., 2008. The new fisheries multibeam echosounder ME70: description and expected contribution to fisheries research. Ices Journal of Marine Science 65, 645-655. doi:10.1093/icesjms/fsn051

Vanreusel, A., Andersen, A.C., Boetius, A., Connelly, D., Cunha, M.R., Decker, C., Hilario, A., Kormas, K.A., Maignien, L., Olu, K., Pachiadaki, M., Ritt, B., Rodrigues, C., Sarrazin, J., Tyler, P., Van Gaever, S., Vanneste, H., 2009. Biodiversity of cold seep ecosystems along the European Margins. Oceanography 22, 110-127

Woodside, J.M., Volgin, A.V., 1996. Brine pools associated with Mediterranean Ridge mud diapirs: an interpretation of echo-free patches in deep tow sidescan sonar data. Marine Geology 132, 55-61. doi:10.1016/0025-3227(95)00153-0 


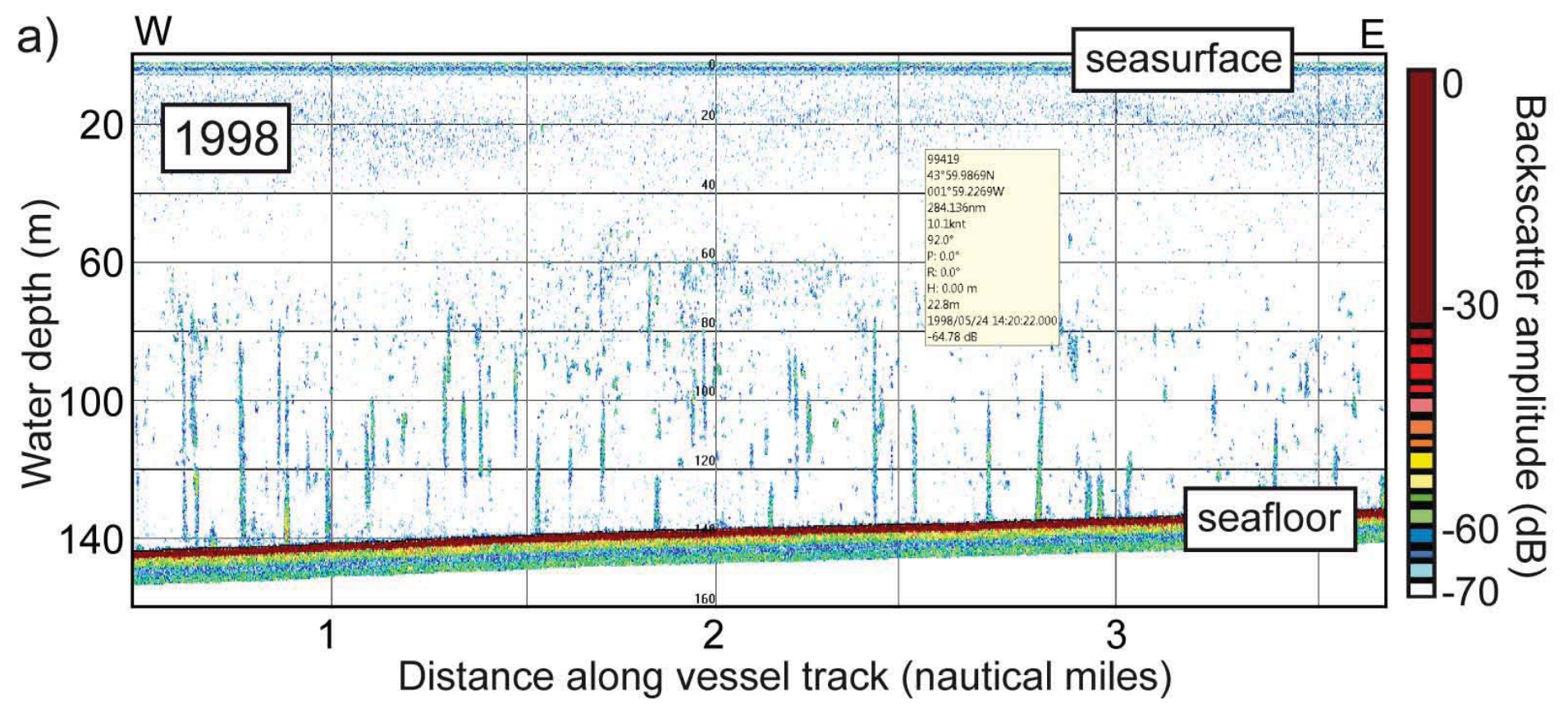

b) $\mathrm{W}$

Distance along vessel track (nautical miles)
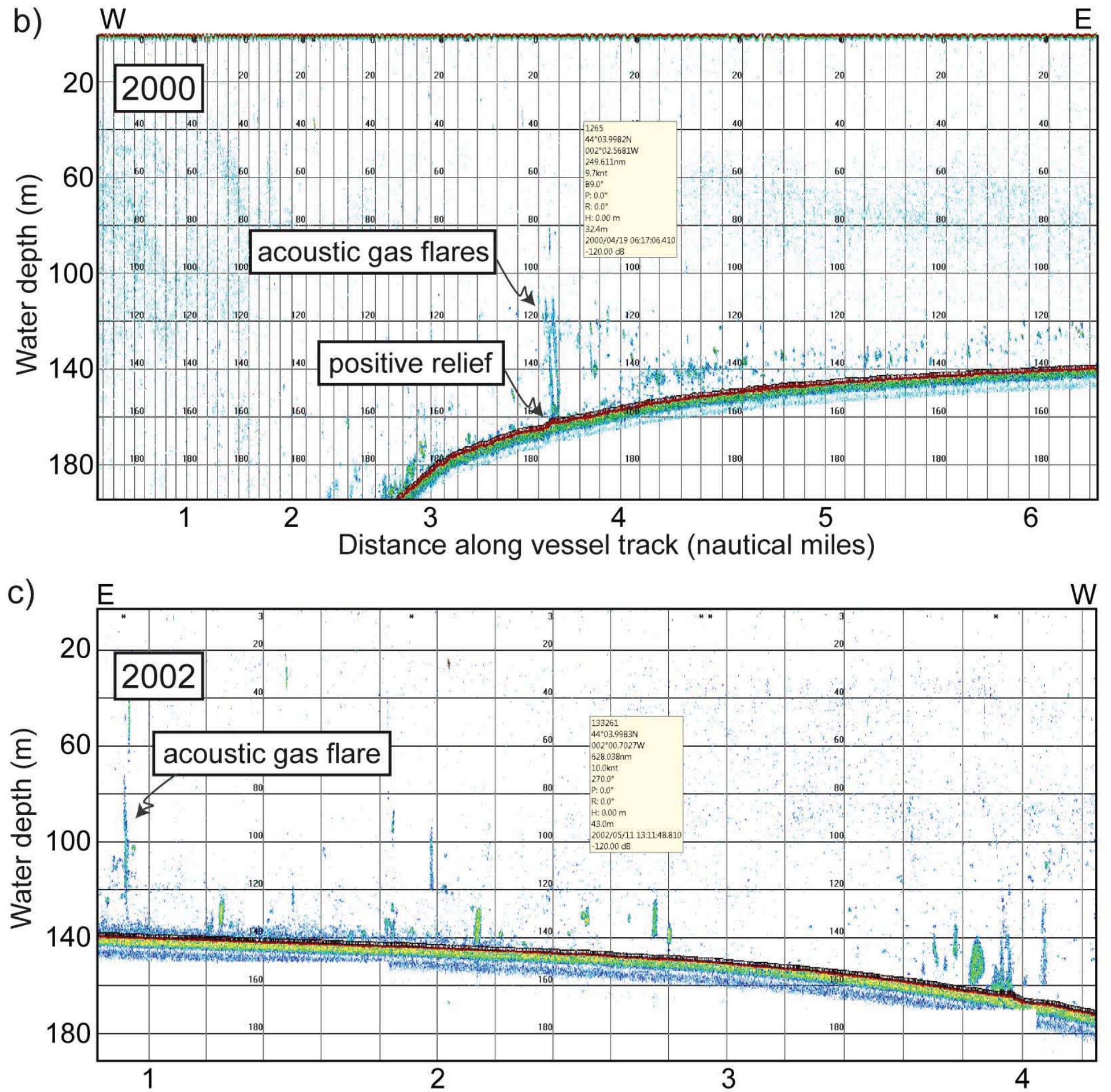

Distance along vessel track (nautical miles) 


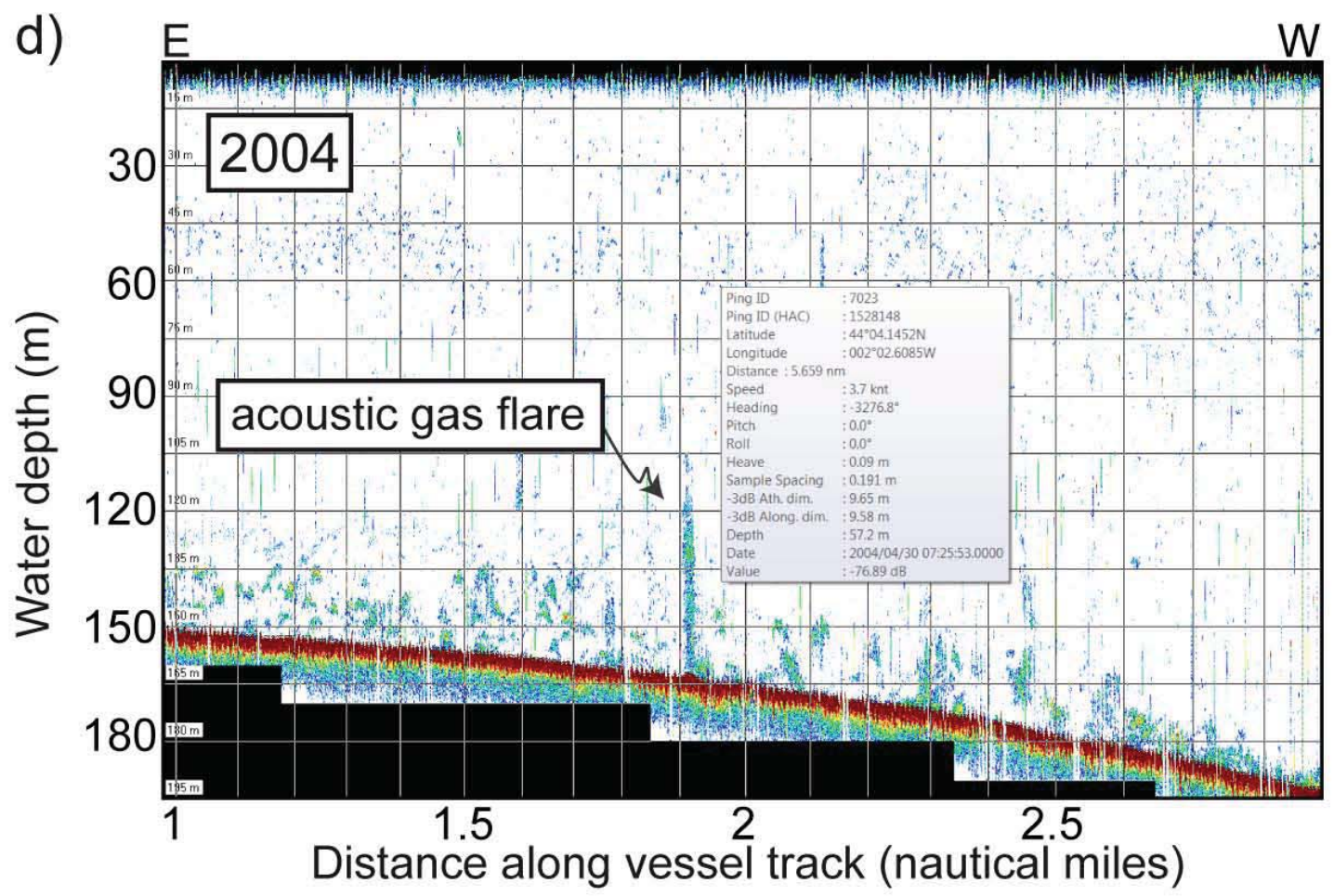

e)
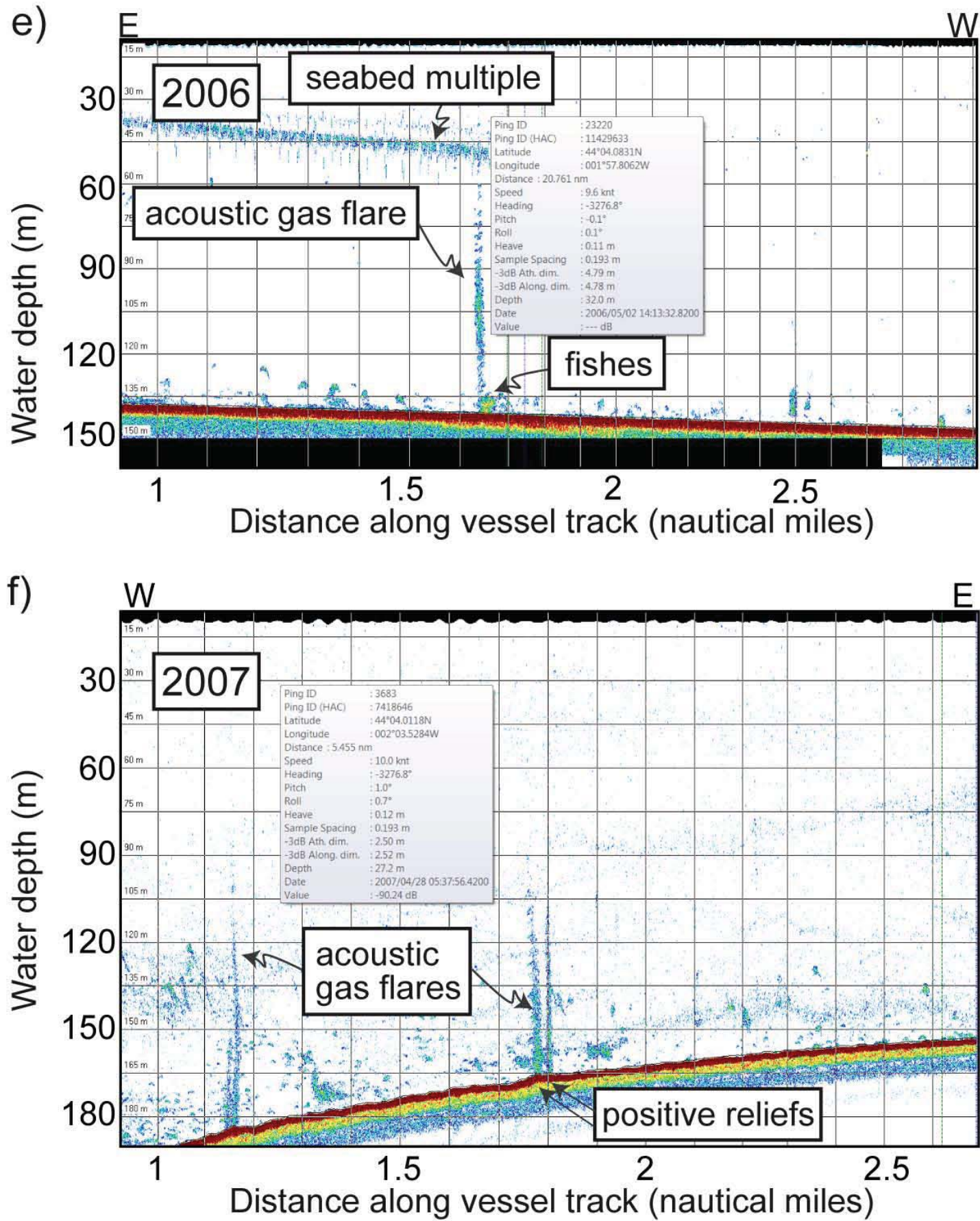

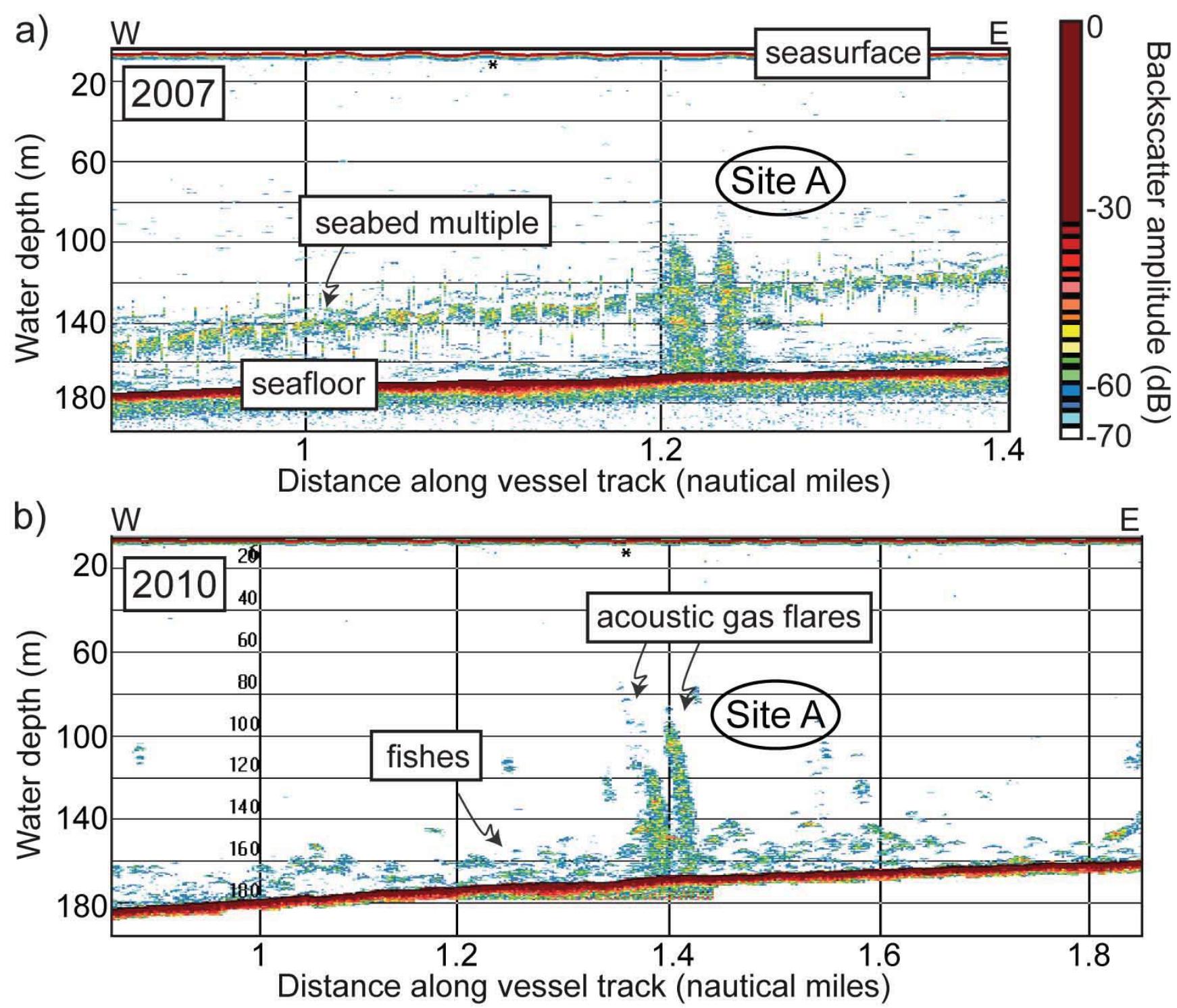

E

c) $\mathrm{W}$

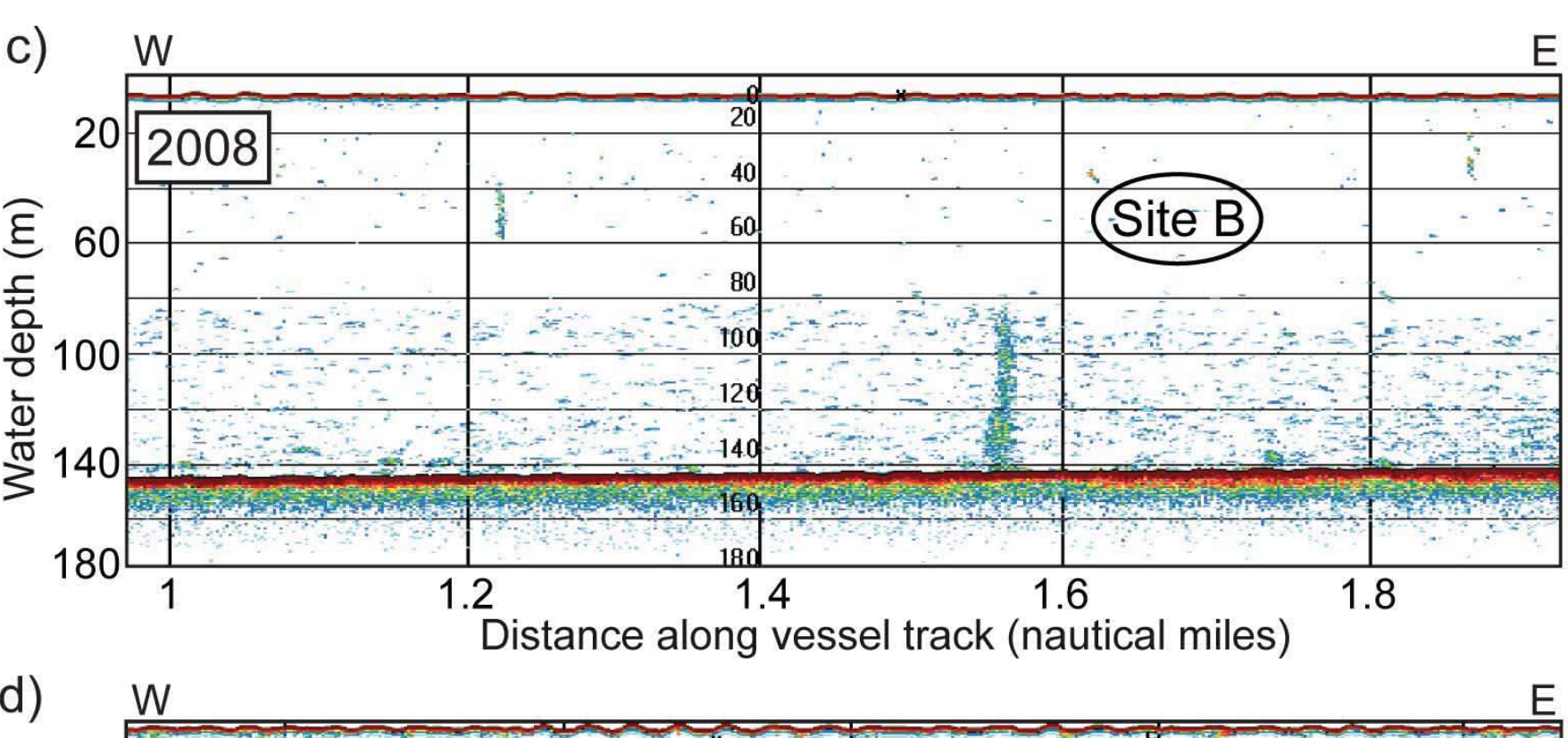

Distance along vessel track (nautical miles)

d)

d)

W

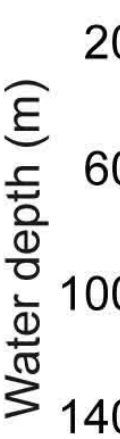

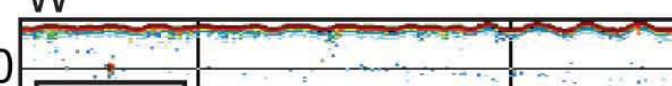




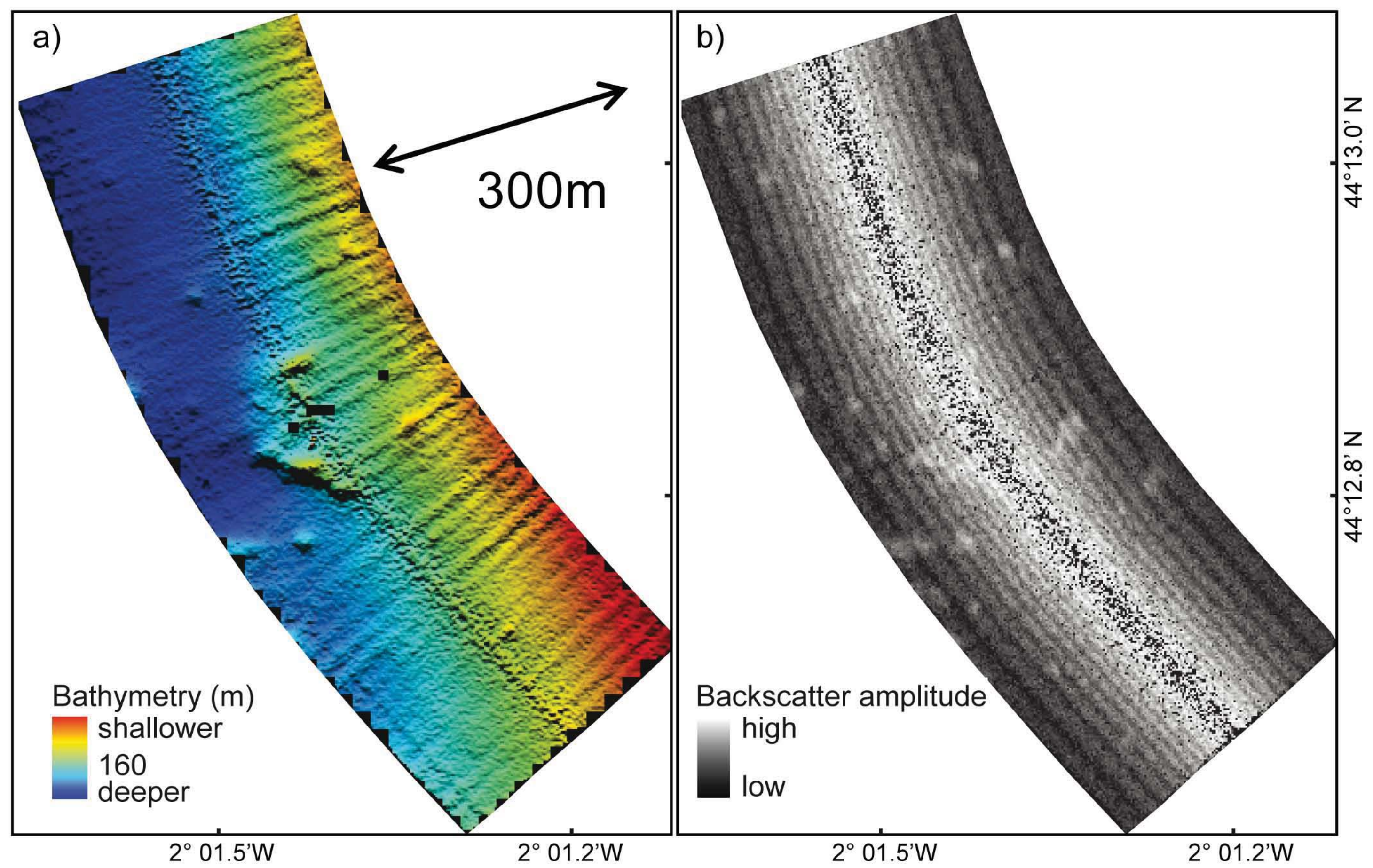




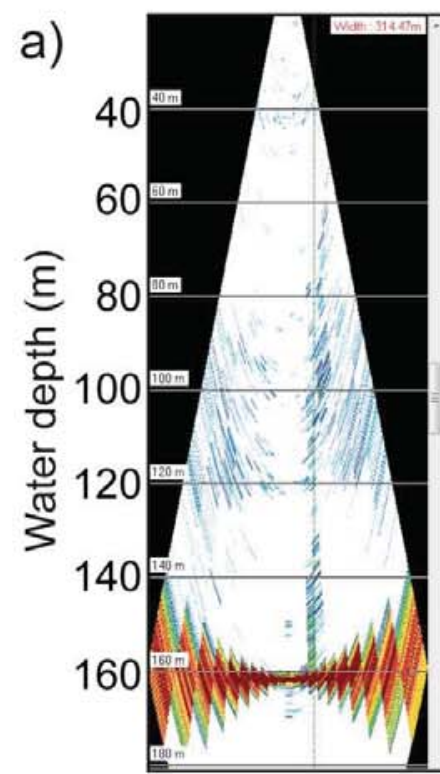

a)

b)

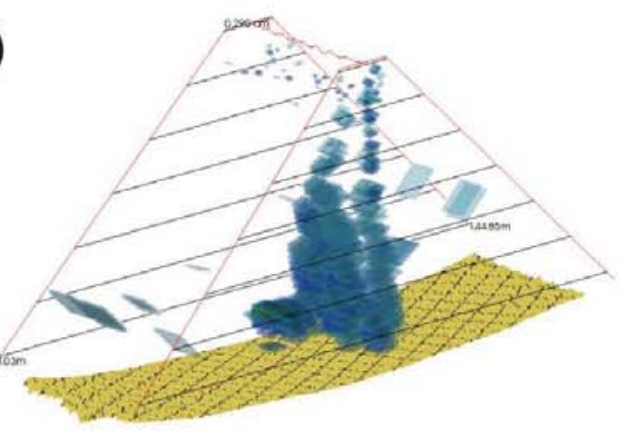

d)

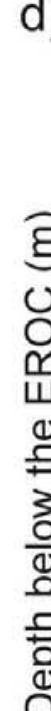

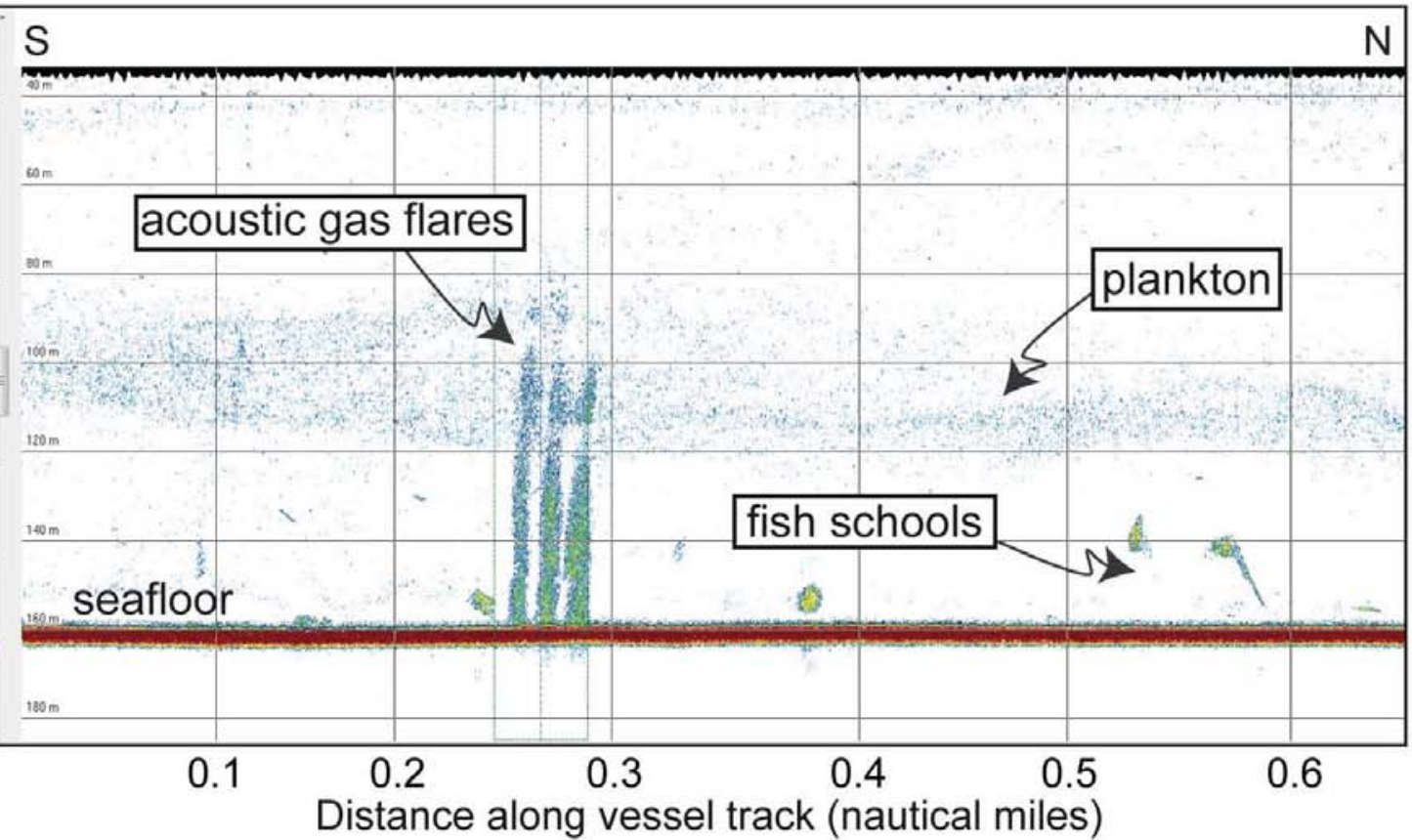

c)
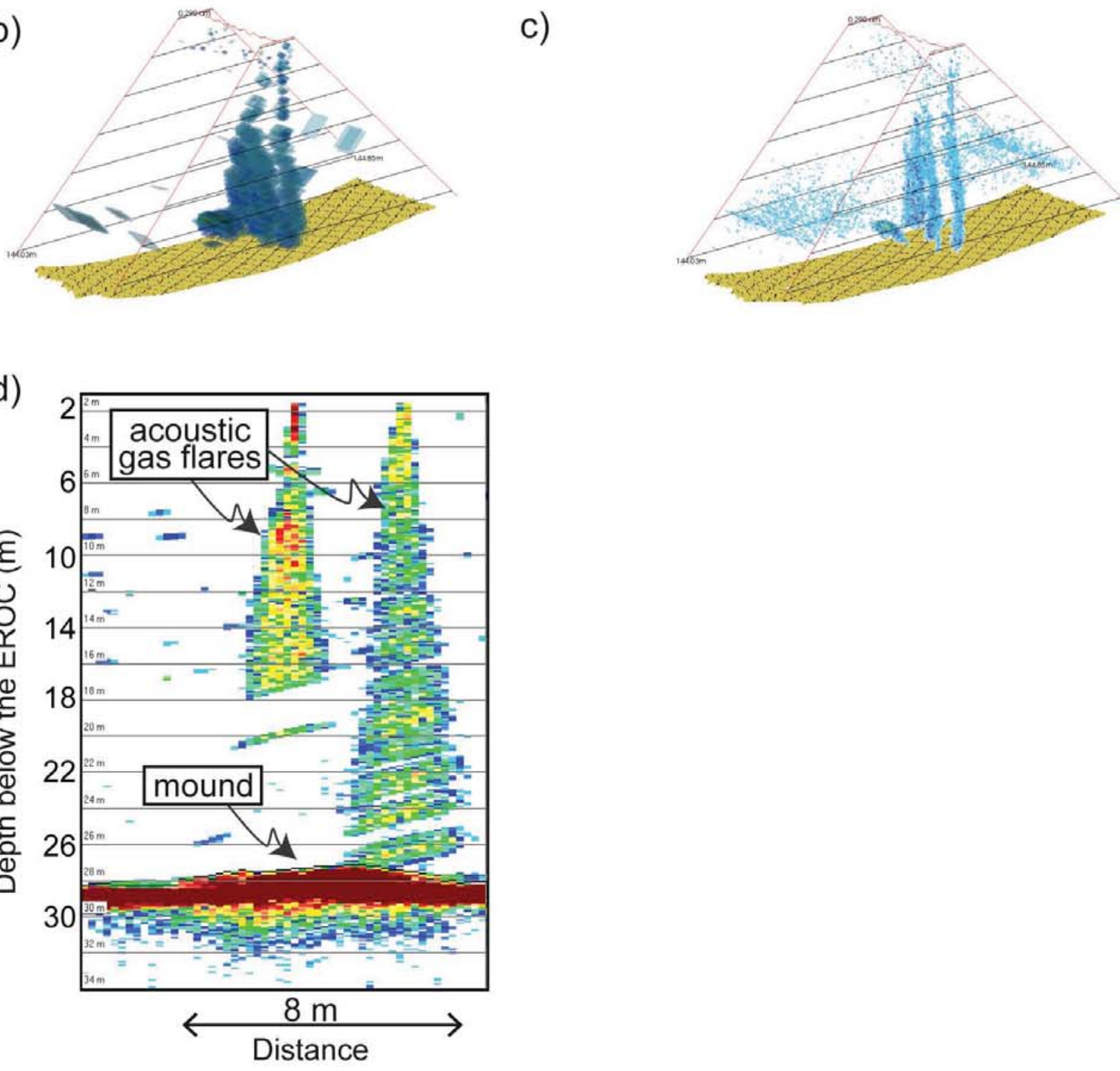


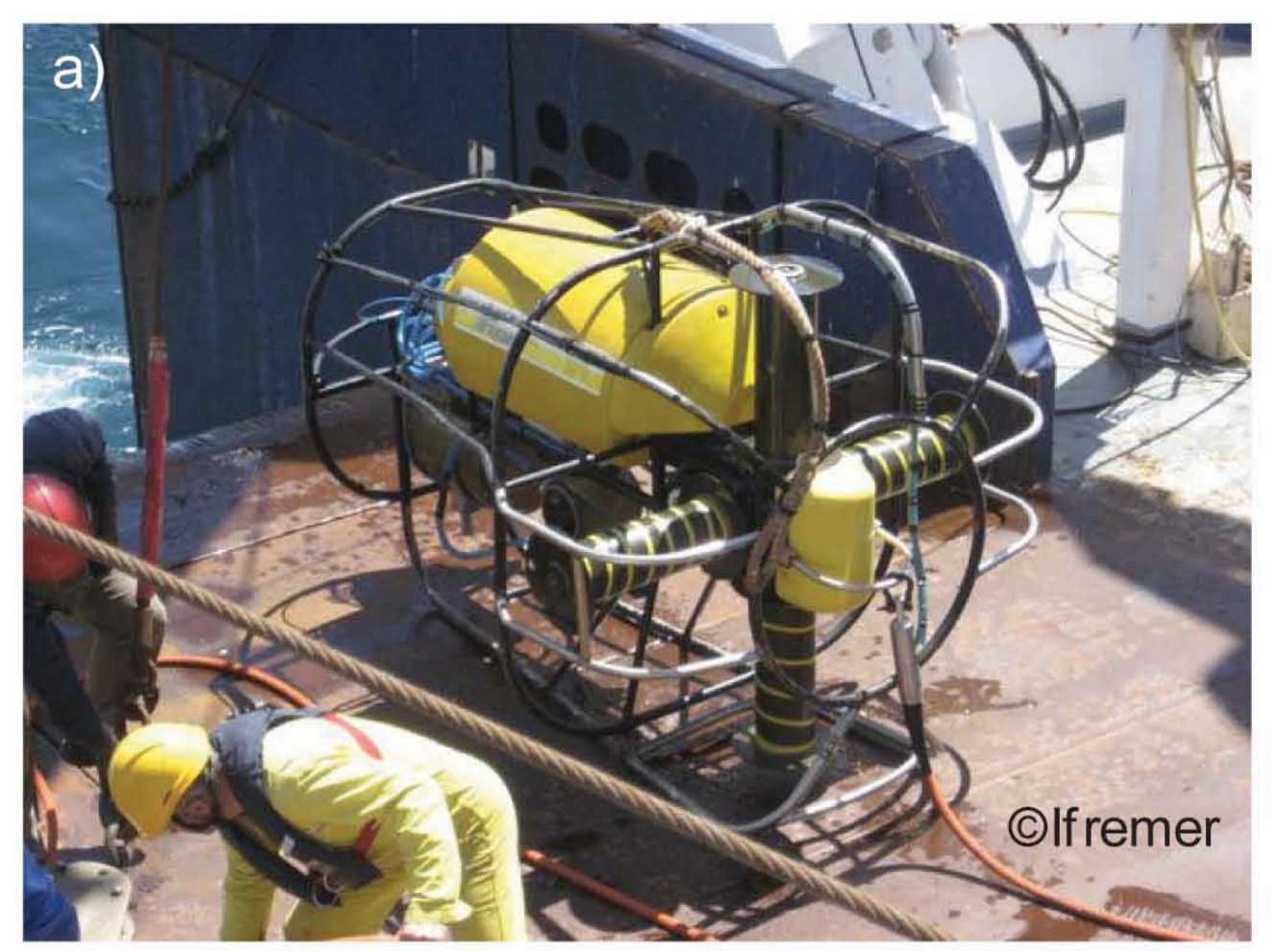

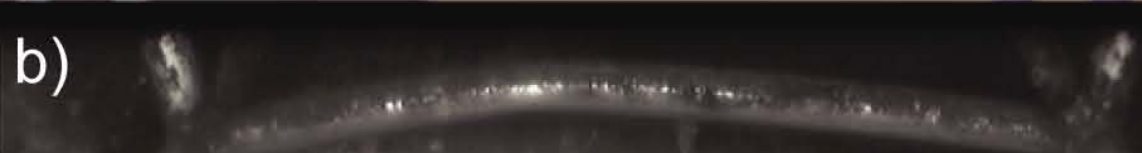

c) $\$$ n 4

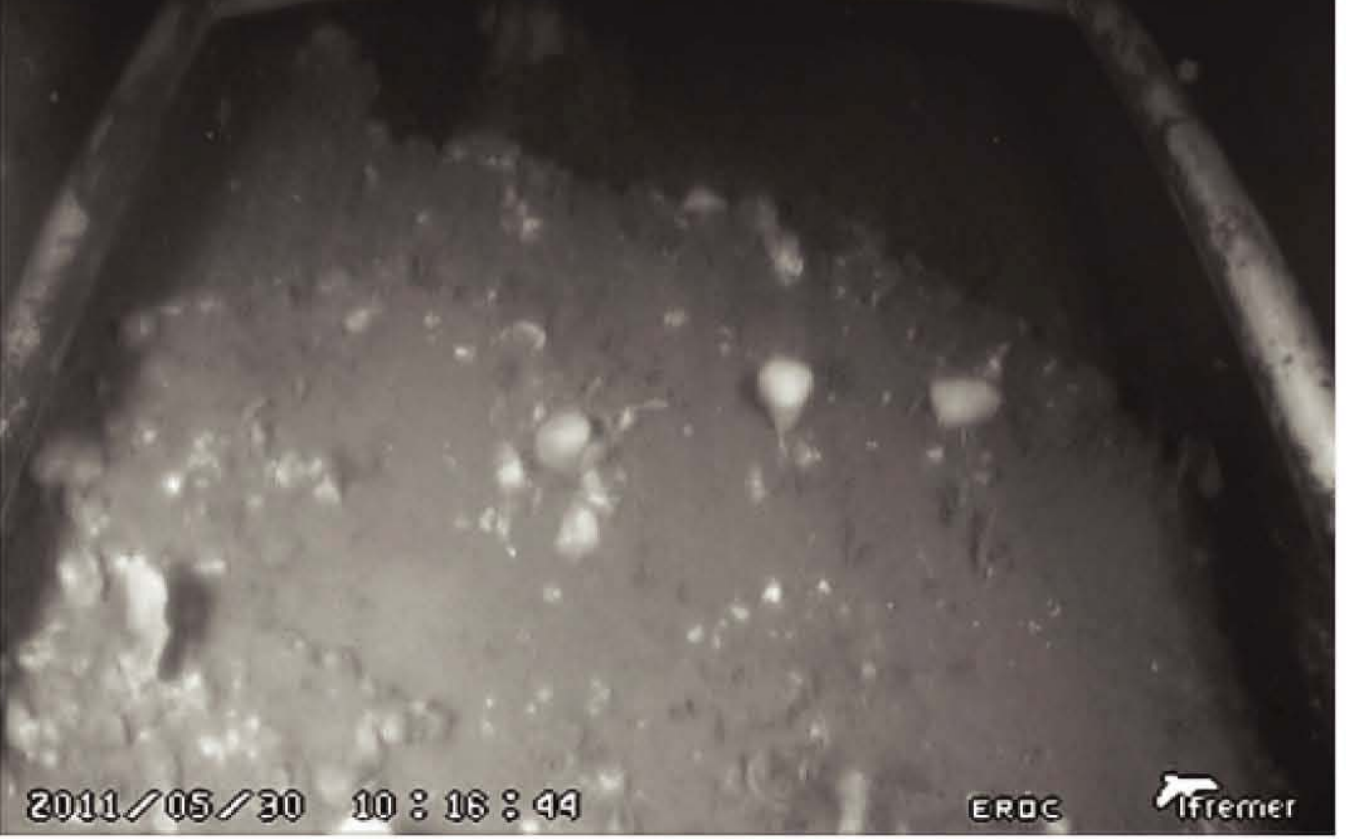

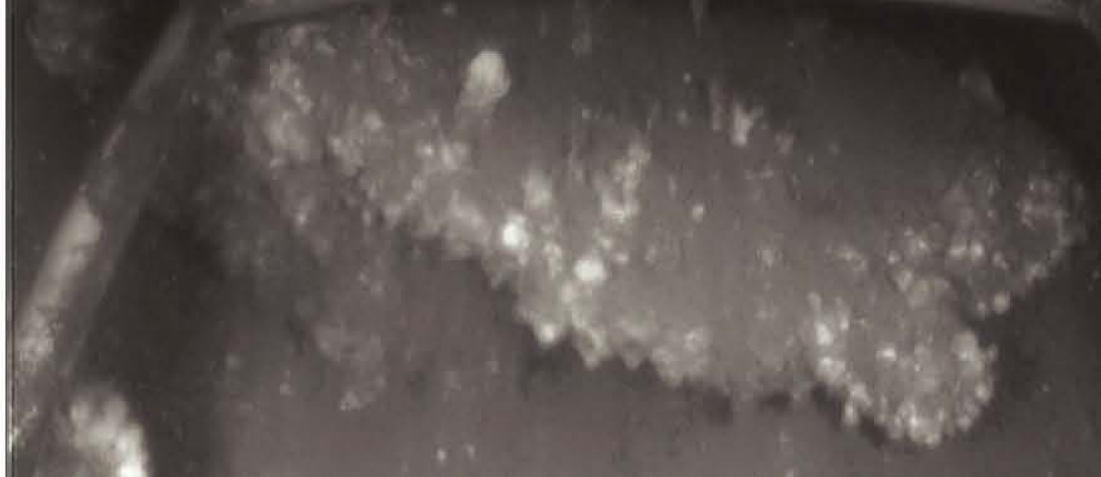

$2011005030 \quad 10: 118: 49$

d)

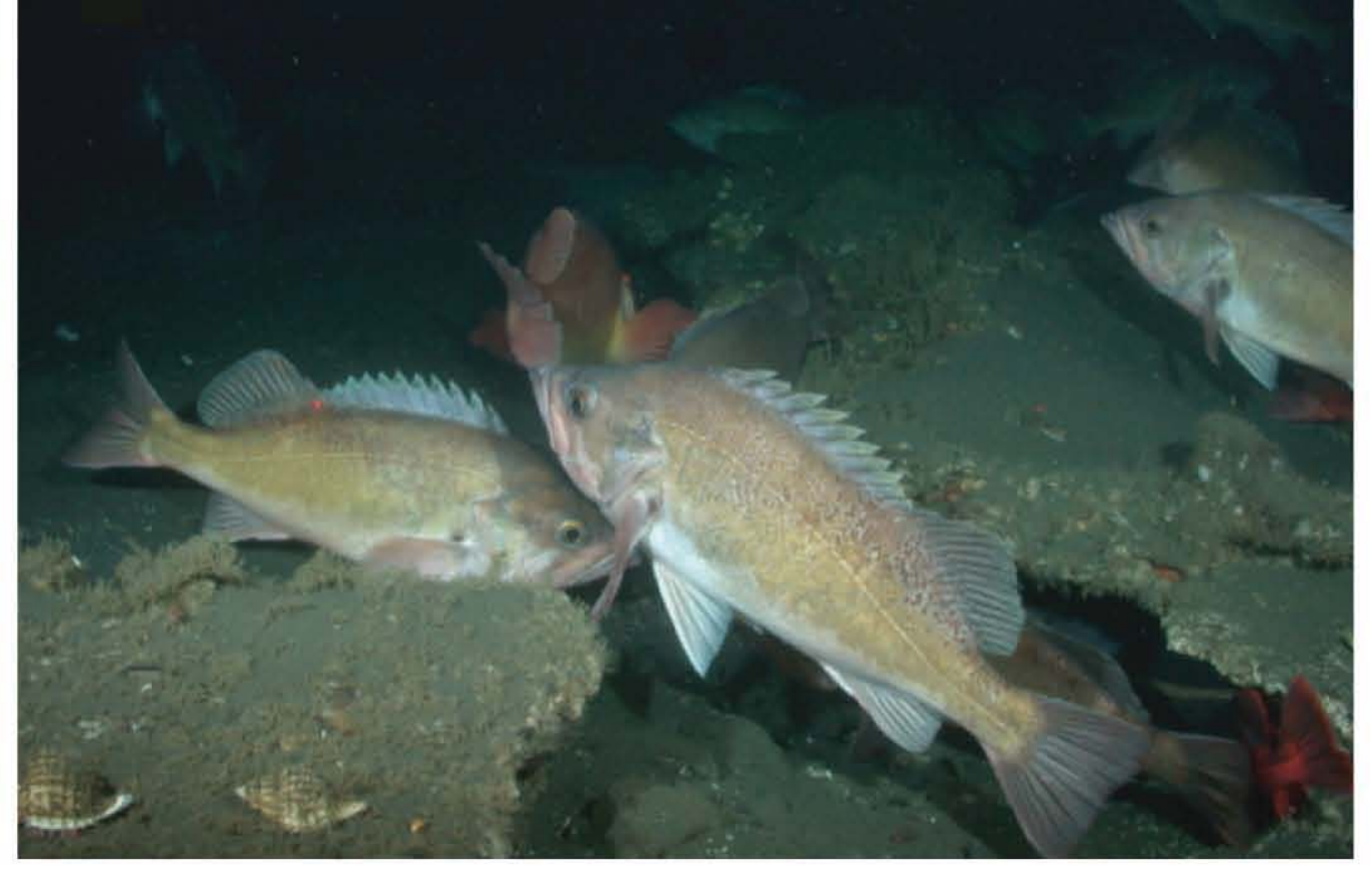


a) Gas emission sites

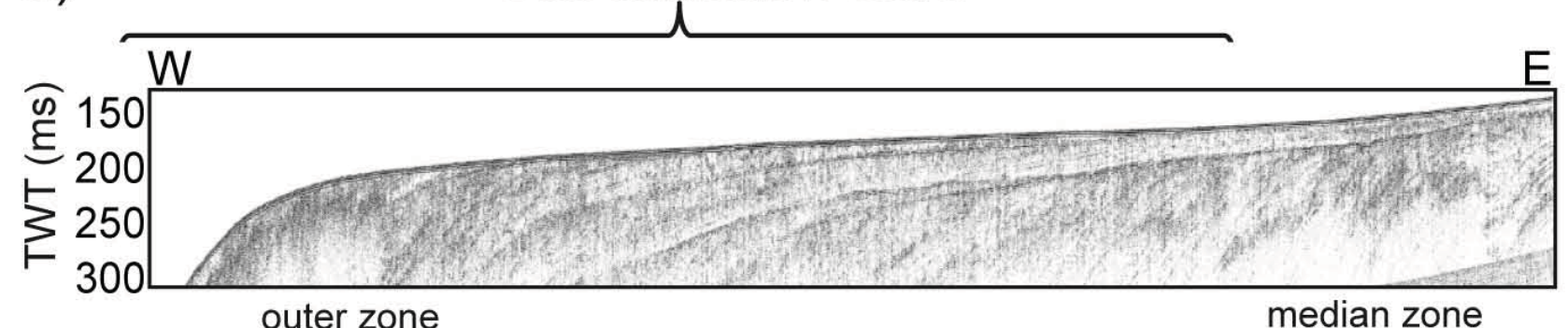

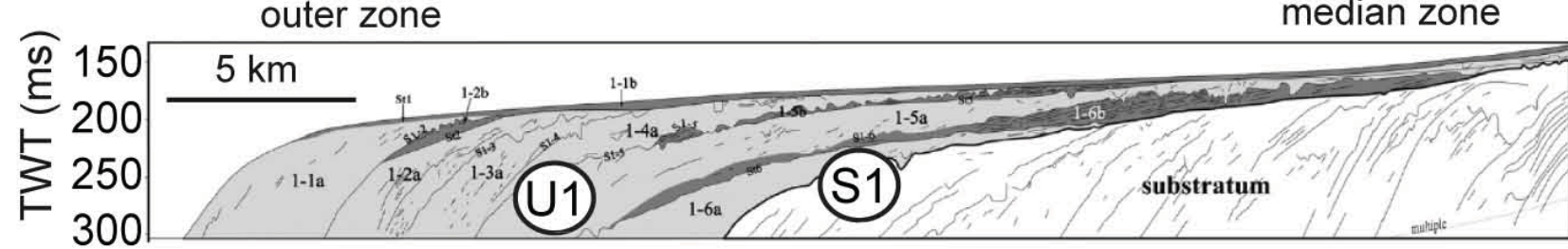

b)

\section{Gas emission sites}

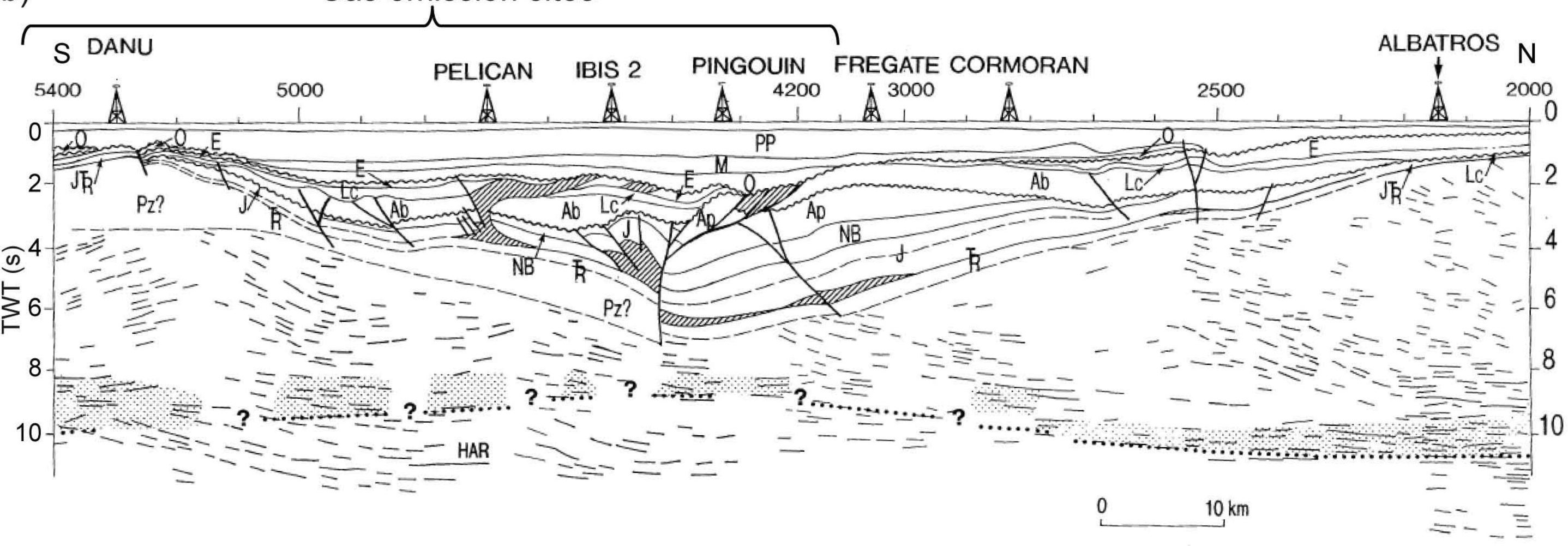

